\title{
MALARIA ASIMTOMATIK: TANTANGAN DALAM PENGENDALIAN MALARIA
}

\author{
Rizka Sofia* \\ Bagian Parasitologi Fakultas Kedokteran Universitas Malikussaleh \\ Lhokseumawe-Aceh, 24352, Indonesia \\ "Corresponding Author: drrizkasofia@gmail.com
}

\begin{abstract}
Abstrak
Penyakit malaria merupakan salah satu masalah kesehatan terbesar di sebagian wilayah negara tropis yang dapat menyerang semua orang dari setiap golongan umur. Patogenesis terjadinya malaria sangat komplek dan dapat menyebabkan gejala klinik yang berat dengan komplikasi, gejala ringan tanpa komplikasi, hingga gejala yang asimtomatik. Pada daerah endemik malaria, proporsi terbesar malaria adalah malaria asimtomatik. Infeksi malaria asimtomatik masih sedikit dimengerti oleh kebanyakan orang. Sebagian besar penderita malaria asimtomatik tidak terdiagnosis dan tidak mendapatkan terapi. Penderita malaria asimtomatik membawa gametosit yang berperan penting dalam penularan penyakit malaria, keadaan ini akan mengakibatkan penderita carrier (pembawa penyakit) atau penderita malaria tanpa gejala klinis (asymptomatic) yang setiap saat dapat menularkan parasit kepada orang lain, sehingga kasus baru bahkan kejadian luar biasa (KLB) malaria bisa terjadi pada waktu yang tidak terduga. Oleh karena itu artikel review ini dibuat untuk mendiskusikan mengenai permasalahan malaria asimtomatik guna perkembangan strategi pengendalian malaria dalam menurunkan angka kejadian penyakit malaria.
\end{abstract}

Kata Kunci: malaria asimtomatik; penularan; patogenesis; strategi pengendalian 


\title{
ASIMPTOMATIC MALARIA: A CHALLENGE IN MALARIA CONTROL STRATEGY
}

\begin{abstract}
Malaria is one of the biggest health problem in some areas of tropical countries that can attack everyone of every age group. Pathogenesis of malaria is very complex and can cause severe clinical symptoms with complications, mild symptoms without complications, and asymptomatics. In the malaria endemic areas, malaria asymptomatic is the biggest proportion of malaria. The infection of asymptomatic malaria is not still completely understood by most people. Many people with asymptomatic malaria are undiagnosed and do not get treatment. Malaria asymptomatic carrying gametocytes that plays an important role in the transmission of malaria, this situation will lead people to be carriers (carriers of disease) or malaria patients without clinical symptoms (asymptomatic) who at any moment can transmit the parasite to others, so that new cases even extraordinary events (EOE) of malaria can occur at unpredictable times. Therefore, this article review is made for discussing the problem of malaria asymptomatic for malaria control strategies development in order to decrease the incidence of malaria.
\end{abstract}

Keywords: asymptomatic malaria; transmission; pathogenesis; control strategies 


\section{Pendahuluan}

Malaria merupakan penyakit menular yang menjadi perhatian global. Penyakit ini masih merupakan masalah kesehatan masyarakat karena sering menimbulkan KLB, berdampak luas terhadap kualitas hidup dan ekonomi, serta dapat mengakibatkan kematian

Pada laporan WHO pada tahun 2013 hampir setengah populasi dunia berisiko malaria. Secara global, diperkirakan 3,3 miliar orang di 97 negara dan wilayah beresiko malaria, dan 1,2 miliar beresiko tinggi (> 1 kasus malaria per 1.000 penduduk setiap tahun). Menurut perkiraan terakhir 198 juta kasus malaria terjadi secara global pada tahun 2013 (berkisar 124 - 283 juta) dan mengakibatkan 584 ribu kematian.

Insiden Malaria di Indonesia tahun 2013 adalah 1,9 persen dan prevalensi malaria tahun 2013 adalah 6,0 persen. Dari 33 provinsi di Indonesia, 15 provinsi mempunyai prevalensi malaria di atas angka nasional, sebagian besar berada di Indonesia Timur.

Penularan malaria dipengaruhi oleh keberadaan dan fluktuasi populasi vektor (nyamuk Anopheles sp) dan sumber parasit Plasmodium sp, di samping adanya host yang rentan. Sumber parasit Plasmodium sp. adalah host yang menjadi penderita positif malaria, akan tetapi di daerah endemis malaria sebagian besar infeksi malaria tidak menunjukkan gejala, ini disebabkan adanya perubahan tingkat resistensi manusia terhadap parasit malaria sebagai akibat tingginya frekuensi kontak dengan parasit, bahkan di beberapa negara terjadinya kekebalan ada yang diturunkan melalui mutasi genetik. Keadaan ini akan mengakibatkan penderita pembawa penyakit (carrier) atau penderita malaria tanpa gejala klinis (asymptomatic). Sebagian besar malaria asimtomatik tidak terdiagnosis dan tidak diobati. Oleh karena itu memainkan peran penting dalam penularan malaria, sehinggakasus baru bahkan kejadian luar biasa (KLB) malaria bisa terjadi pada waktu yang tidak terduga.

Sebuah penelitian di Senegal melaporkan bahwa lebih dari 90\% dari individu yang terkena yang kemungkinan terinfeksi malaria asimtomatik kronis (Laishram et al, 2012). Pada penelitian lain pada daerah endemis malaria di Bangladesh didapatkan prevalensi malaria sebesar $30,7 \%$ dengan proporsi kasus malaria asimtomatik yang dikonfirmasi PCR adalah $77,0 \%$, dan kasus malaria dengan gejala hanya 19,8\%. Secara signifikan lebih banyak kasus malaria asimtomatik pada usia lebih dari 15 tahun.

Infeksi malaria asimtomatik memainkan peran penting dalam penularan malaria. Hal ini merupakan pengaruh besar bagi program pengendalian malaria berkelanjutan yang didasarkan pada pengobatan pasien dengan gejala sehingga diperlukan strategi baru yang menargetkan infeksi malaria tanpa gejala.

\section{Etiologi Peyakit Malaria}

Malaria merupakan penyakit infeksi yang disebabkan oleh parasit Plasmodium. Penyakit ini disebarkan oleh nyamuk Anopheles betina dan perkembangbiakannya sangat tergantung pada faktor lingkungan setempat, kedekatan antara lokasi perkembang-biakan nyamuk dengan manusia dan jenis nyamuk di wilayah tersebut. Patogenesis terjadinya malaria sangat komplek, dan menyebabkan gejala klinik yang berat dengan komplikasi, gejala ringan tanpa komplikasi, hingga gejala yang asimtomatik.

\section{Malaria Asimtomatik}

Dari empat spesies parasit malaria manusia, Plasmodium falciparum dilaporkan menyebabkan morbiditas dan mortalitas tertinggi. Anak-anak dengan sistem kekebalan tubuh yang lemah, ibu hamil, 
tergolong populasi resiko tinggi menyebabkan kematian akibat penyakit malaria. Penyakit malaria akibat P.falciparum dapat menyebabkan gejala yang berat dengan komplikasi, gejala ringan tanpa komplikasi bahkan malaria asimtomatik. Pada malaria berat memiliki satu atau lebih dari manifestasi klinis berikut: koma (disebabkan malaria secerbral), kejang, anemia, hemoglobinuria, hipoglikemia, asidosis metabolik (terkait dengan gangguan pernapasan), edema paru akut, gagal ginjal akut, penyakit kuning, kolaps sirkulasi, hiperparasitemia, gangguan elektrolit demam tinggi, dan perdarahan spontan.

Sebaliknya, individu dengan malaria ringan atau tanpa komplikasi biasanya mengalami demam dan memiliki satu atau lebih dari gejala berikut: menggigil dan berkeringat, sakit kepala, muntah, diare, anemia, penyakit kuning, dan pembengkakan limpa (splenomegali). Jika didiagnosis dengan benar dan mendapatkan terapi, prognosis baik untuk pasien dengan malaria ringan tanpa komplikasi.

Malaria asimtomatik adalah seseorang tanpa gejala atau tanda malaria tetapi hasil laboratorium menunjukkan parasitemia. ${ }^{8}$ Malaria asimtomatik sukar untuk didiagnosis dikarenakan kurang jelasnya manifestasi klinis dan sering tidak terdeteksi dengan mikroskop dan sebagian besar hanya dapat ditegakkan dengan PCR. Malaria asimtomatik memiliki prevalensi yang tinggi pada daerah endemis dan menjadi perhatian yang serius karena malaria asimtomatik juga dapat menularkan. Sebagai contoh studi di Senegal menyatakan bahwa lebih dari 90\% individu yang menderita malaria asimtomatik dapat bertindak sebagai reservoir untuk transmisi malaria. Selama lebih dari dua dekade, peneliti telah menyelidiki pengembangan dua jenis imunitas yang dapat mengakibatkan malaria asimtomatik.
Kekebalan anti-penyakit yang memungkinkan seseorang menjadi carrier (Parasitemia tanpa gejala) kekebalan antiparasit yang mungkin bertanggung jawab menekan parasit pada usia tertentu, yang kemungkinan terkait faktor paparan imunitas klinis. Beberapa laporan yang tersedia menyatakan penyebab terbanyak tmalaria asimtomatik adalah P.falciparum.

Kriteria yang banyak digunakan untuk diagnosis malaria asimtomatik adalah adanya parasit di apusan darah tebal perifer, suhu aksila $<37,5 \circ \mathrm{C}$, dan tidak adanya gejala malaria. Namun, ambang parasit universal standar untuk mengklasifikasi infeksi malaria asimtomatik belum dapat didefinisikan. Meskipun penggunaan PCR spesifik yang mungkin tidak selalu tersedia di bidang, atau bahkan mungkin praktis untuk menguji infeksi yang negatif dengan menggunakan mikroskop, PCR merupakan alat yang ampuh untuk menemukan malaria asimtomatik dalam suatu populasi.

\section{Patogenesis Malaria Asimtomatik}

Plasmodium sp. melakukan proses kehidupan yang meliputi metabolisme, pertumbuhan, berkembang biak dan mempunyai reaksi terhadap rangsangan. Plasmodium sp. berkembang biak secara seksual dan aseksual. Pembiakan seksual terjadi di dalam tubuh nyamuk melalui proses sporogoni. Bila mikrogametosit (sel jantan) dan makrogametosit (sel betina) terhisap oleh vektor bersama darah penderita. Dari proses ini akan terbentuk zigot yang kemudian akan berubah menjadi ookinet dan selanjutnya menjadi ookista. Terakhir ookista pecah dan membentuk sporozoit yang tinggal dalam kelenjar ludah vektor. Perubahan ini disebut siklus sporogoni. Jumlah sporokista pada setiap ookista dan lamanya siklus sporogoni, pada masing-masing spesies Plasmodium berbeda. Jumlah sporozoit $P$. vivax dalam ookista adalah 30-40 butir dan siklus sporogoni 
selama 8-9 hari, sporozoit $P$. falciparum adalah 10-12 butir dan siklus sporogoni selama 10 hari, $P$. malariae adalah 6-8 butir dan siklus sporogoni selama 26-28 hari.

Pembiakan aseksual terjadi di dalam tubuh manusia melalui proses schizogoni yang terjadi melalui proses pembelahan sel secara ganda. Nyamuk yang mengandung sporozoit dalam kelenjar ludahnya, menggigit manusia mengeluarkan air ludahnya dan sporozoitnya ikut masuk kedalam tubuh manusia. Pada tubuh manusia, sporozoit dalam waktu 1/2-1 jam sudah masuk kedalam jaringan hati. Sporozoit dari $P$. vivax dan $P$. ovale sebagian berubah menjadi hypnosoit, sebagian lagi berubah menjadi schizon hati. Sedangkan sporozoit $P$. falciparum dan P.malariae, semuanya berubah menjadi schizon hati.

Hypnosoit P.vivax dan P.ovale sewaktuwaktu bisa berubah menjadi schizon hati. Karena itu untuk P.vivax dan P.ovale dikenal adanya rekurensi. Schizon hati mengandung ribuan merozoit yang akan pecah dan keluar dari jaringan hati untuk kemudian masing-masing merozoit ini menginvasi sel darah merah. Tropozoit berkembang biak secara aseksual yang kemudian ruptur dan mengeluarkan eritrositik merozoit, yang secara klinis ditandai dengan demam. Merozoit yang telah masuk ke dalam sel darah merah, kemudian berubah menjadi bentuk tropozoit.

Tropozoit ini selanjutnya membentuk schizon darah yang mengandung merozoit. schizon matang mengalami sporulasi yaitu melepaskan merozoit untuk kemudian menginvasi sel darah merah baru. Beberapa dari merozoit ini berkembang menjadi gametosit jantan dan gametosit betina, sekaligus melengkapi fase siklus aseksual pada manusia. Gametosit jantan dan gametosit betina ini dicerna oleh nyamuk Anopheles betina saat mengisap darah dari manusia. Dengan adanya proses-proses pertumbuhan dan pembiakan aseksual didalam sel darah merah manusia, maka dikenal ada tiga stadium Plasmodium yaitu stadium tropozoit (proses pertumbuhan), stadium schizon (proses pembiakan), stadium gametosit (proses pembentukan sel kelamin).

Masih belum jelas mengapa beberapa infeksi $P$. falciparum tidak menunjukkan gejala, tetapi faktor-faktor parasit mungkin terlibat, seperti kepadatan parasit, produksi toksin, dan keragaman genetik termasuk ekspresi virulensi. Secara umum, parasitemia telah dikaitkan dengan tingkat keparahan penyakit, namun hal ini tidak selalu terjadi. Sebuah studi di Kepulauan Solomon menunjukkan bahwa individu yang terinfeksi $P$. vivax dan $P$. falciparum tanpa gejala cenderung memiliki kepadatan parasit rendah. Studi lain menyimpulkan asosiasi kepadatan parasit parasitemia asimtomatik yang lebih tinggi dengan malaria dengan gejala. Sebuah studi yang menyelidiki hubungan kepadatan parasit pada jumlah trombosit menunjukkan bahwa anak-anak yang terinfeksi malaria dengan trombositopenia masih muda, memiliki parasitemia tinggi.

Sistem imunitas penderita sangat mempengaruhi manifestasi klinis malaria. Berbagai penelitian telah menyelidiki keragaman genetik P.falciparum dan hubungannya dengan perkembangan gejala klinis. Ada bukti kuat bahwa kekebalan terhadap malaria khusus untuk strain tertentu memunculkan respon host, yang memungkinkan seorang individu untuk melawan infeksi oleh strain tertentu, tapi tidak dengan yang heterolog; ini telah disebut 'kekebalan strain-spesifik.

Daya imunitas malaria adalah spesies spesifik, seseorang yang imun terhadap malaria vivax akan terserang penyakit malaria lagi bila terinfeksi oleh malaria falciparum. Orang yang berkulit hitam akan tahan terhadap infeksi malaria vivax dari pada orang yang berkulit putih, sedangkan malaria falciparum pada orang hitam tidak begitu berbahaya. 
Studi-studi lain telah memicu penyelidikan terhadap karakteristik molekuler gejala-spesifik berdasarkan polimorfisme antigen permukaan yang telah diidentifikasi diisolat yang dikumpulkan dari malaria asimtomatik, tanpa komplikasi, dan kasus malaria berat di berbagai wilayah geografis. Antigen permukaan polimorfik tersebut meliputi famili merozoite surface protein (MSP), apical membrane antigen 1 (AMA1), erythrocyte binding antigen-175 (EBA-175), dan knob-associated histidine rich protein (KAHRP). Polimorfisme antigenik tertentu memungkinkan parasit untuk menghindari respon imun pada pasien dengan infeksi kronis dan dengan demikian dapat berperan dalam kelangsungan hidup parasit di host manusia sampai memungkinkan terjadinya penularan.

Sebuah aspek penting dari virulensi $P$. falciparum adalah kemampuan eritrosit yang terinfeksi untuk menyerap dan menghalangi mikrovaskulatur pada organ yang berbeda. Cytoadhesion pada sel endotel dimediasi oleh peningkatan densitas-elektron membran parasit yang disebut sebagai knobs terutama terdiri dari KAHRP. Pada satu studi, ditemukan tiga alel yang berbeda (340 bp, 370 bp dan 400 bp) pada kasus-kasus ringan, tetapi hanya dua bentuk (340 bp dan 370 bp) yang diamati pada kasus berat. Studi ini menghubungkan alel KAHRP dengan tingkat keparahan malaria dari perluasan malaria asimtomatik.

\section{Penularan Penyakit Malaria Asimtomatik}

Transmisi penularan malaria sangat kompleks, tergantung pada faktor-faktor seperti iklim, lokasi tempat perkembangbiakan nyamuk, dan pemukiman manusia sebagai reservoir parasit infeksi nyamuk. Infeksi tanpa gejala sering tidak terdeteksi sehingga tidak mendapatkan pengobatan, sehingga menjadi sumber utama gametosit untuk vektor nyamuk. Infeksi $P$. falciparum telah terbukti bertahan asimtomatik pada individu semi imun selama lebih dari 18 bulan.

Sebuah korelasi positif antara transmisi dan prevalensi tanpa gejala telah dilaporkan di Nigeria, Senegal, Gabon dan wilayah Amazon Brazil. Tingginya tingkat prevalensi malaria asimtomatik dalam wilayah penularan tinggi mungkin disebabkan karena paparan terkait imunitas. imunitas terkait dengan idividu yag mendapatkan paparan parasit dalam periode waktu yang lama sehingga mengembangkan memori imunologi.

\section{Pengobatan dan Pengelolaan Malaria Asimtomatik}

Terapi pengobatan sering dikaitkan dengan perkembangan gametosit, penghancuran tahap aseksual yang menstimulasi perkembangan parasit tahap sexual. Saat ini mayoritas terapi pengobatan malaria didasarkan pada tahap asexual dari $P$. falciparum. Peng-obatan rejimen yang mengandung artemisinin dan atau turunannya dilaporkan untuk menurunkan carrier gametosit da mengurangi infektivitas penularan individu. Terapi kombinasi Artemisinin (ACT) yang dianjurkan sebagai terapi lini pertama pada malaria dilaporkan cukup efisien untuk mengurangi bahkan pada level gametosit submikroskopik.

Artemeter-lumefantrine, sebuah (ACT) telah disarankan sebagai Intermittent preventive treatment (IPT) pengobatan malaria asimtomatik. Primakuin obat yang banyak digunakan pada malaria $P$. vivax dan $P$. falciparum namun efek yang menyebabkan defisit enzim G6PD harus dipertimbangkan sebelum diberikan pengobatan. Kombinasi Primakuin dengan sulphadoxine-pyrimethamine dan artesunate aman dan sangat efisien untuk menghilangkan gametosit $P$. falciparum, perkembangan parasit tahap aseksual yang terdeteksi mikroskop, dan gametosit submikroskopik.

Malaria asimtomatik merupakan 
tantangan baru bagi rencana strategis nasional untuk pencegahan dan pengendalian malaria. Situasi di mana malaria asimtomatik tidak didiagnosis, karena mereka tidak menunjukkan gejala. Di sisi lain mendiagnosa kasus tersebut menjadi sulit karena rendahnya tingkat parasitemia.

\section{Strategi Pencegahan Penularan Malaria Asimtomatik}

Plasmodium yang ada pada orang yang tidak menunjukkan gejala klinis, keberadaannya susah diketahui karena pada program pemberantasan malaria, pemeriksaan parasit hanya dilakukan pada orang yang memiliki gejala klinis umum malaria, maka akan terus jadi sumber penularan yang setiap saat bisa menularkan parasit.

Kelompok penduduk yang berisiko tinggi tertular malaria khususnya pada daerah endemis malaria, supaya menjadi prioritas dalam program pemberantasan malaria. Penduduk yang mempunyai risiko tinggi untuk tertular malaria adalah pada kelompok umur 1-5 tahun dan kelompok $>15$ tahun.

Studi lain menunjukkan bahwa seperempat dari wanita hamil memiliki parasitemia malaria asimtomatik dan RDT dapat menjadi instrumen yang sangat berharga untuk diagnosis malaria di daerah pedesaan. Oleh karena itu perlu direkomendasikan skrining parasit malaria rutin untuk semua ibu hamil.

Selain itu keberadaan vektor juga sangat mempengaruhi penularan malaria asimtomatik, misalnya melalui program perlindungan dari gigitan nyamuk dengan pemasangan kelambu atau pemasangan kain kasa pada setiap ventilasi menghidari nyamuk masuk ke dalam rumah.

\section{Daftar Pustaka}

1. Balitbang Kemenkes RI. 2013. Riset Kesehatan Dasar; RISKESDAS. Jakarta: Balitbang Kemenkes RI.

2. World Health Organization. 2014. World Malaria Report 2014. Geneva: WHO Press.

3. Hakim L. 2011. Malaria: Epidemiologi dan Diagnosis. Aspirator Vol. 3 No. 2: 107-116.

4. Zhou G, Yaw AA, Sameer M, Andrew KG and Guiyun Y. 2015. Active case surveillance, passive case surveillance and asymptomatic malaria parasite screening illustrate different age distribution, spatial clustering and seasonality in western Kenya. Malaria Journal 14:41.

5. Starzengruber $\mathrm{P}$, Hans PF, Benedikt L, Kamala T, Paul S,Verena EH, Mariella J, Wolfgang G, Wasif AK, Rashidul H, dan Harald N. 2014. High prevalence of asymptomatic malaria in south-eastern Bangladesh. Malaria Journal, 13:16.

6. Mading M dan Rais Y. 2014. Respon Imun terhadap Infeksi Parasit Malaria. Jurnal Vektor Penyakit, Vol. 8 No. 2: 45 52.

7. Laishram DD, Patrick L S, Nutan N, Vijay LS, Ranbir CS, Jane MC dan Hema J. 2012. The Complexities of Malaria Disease Manifestations with a Focus on Asymptomatic Malaria. Malaria Journal, 11:29.

8. Worku, Ligabauw, Demekech Damtie, Mengistu Endris, Sisay Getie, and Mulugeta Aemero.2014.Asymtomatic Malaria and Associated Risk Factors Among School Children in Sanja Town Northwest Ethiopia.Research Articles International Scholarly Research Notices. Hindawi Publishing Corporation. 
9. Hakim, L dan Sugianto. 2009. Prevalensi Malaria Asymptomatic pada Kelompok Penduduk Paling Berisiko Tertular di Kecamatan Kalipucang Kabupaten Ciamis Jawa Barat. Aspirator Vol. 1 No.1: 04-10.

10. Nwaneri DU, Adeleye OA dan Ane AB. 2013. Asymptomatic Malaria Parasitaemia Using Rapid Diagnostic Test in Unbooked Pregnant Women in Rural Ondo-South District, Nigeria. Journal of preventive medicine and hygiene 54: 49-52. 